Fengshi Wu

\title{
CHINA'S ASCENT IN GLOBAL GOVERNANCE AND THE ARCTIC
}

The paper explains the tendencies of China's Arctic policy by locating them in general patterns of China's uneven rise in global governance across many subject areas. Among the four major pathways of China's enhanced participation in global governance, the Arctic case is best explained by the 'push in' pathway, where a significant increase of lobbying and activities of engagement can be found. The paper highlights that the Arctic is an issue area where China will experiment with new tactics to exert influence on the reform of existing multilateral institutions and to promote its own normative principles for global governance. Refs 33. Table 1.

Keywords: Arctic affairs, China, international relations, global governance

\section{Introduction}

China has transformed from a remotely relevant party to an active permanent observer of the Arctic Council in less than a decade's time. Many researchers have correctly pointed out that China's increasingly evident ambitions targeting the Arctic are primarily driven by its economic pursuits related to energy, fishing and shipping [1-6]. This paper, however, takes a different conceptual angle and locates China-Arctic relations in the overall development of China's engagement with global governance since the new millennium. The purpose of this research is not to speculate on the immediate incentives or outcomes, but to search for the general tendency of China's stance on Arctic governance. The main logic is that, besides contingent negotiations and power structures of the international system, China-Arctic relations are also shaped by a momentum of their own, which is embedded in the rise of China in global governance at large.

The paper consists of three substantive parts. The first part reviews China's uneven participation in international institutions across issue areas. Although China's integration into the global market system and international financial institutions has been smooth, it is still excluded in many other strategic areas of global governance such as energy. The next part explains four different pathways of change in China's behavior with regard to various international governing institutions, and argues that China-Arctic relations will follow the fourth pathway which predicts China will push into the existing governing structures with active advocacy, lobbying and outside activities. The third part outlines the three-fold implication of the 'push in' strategy for Arctic governance, and explicates the specific tactics China has applied to enhance its political presence in the Arctic. The paper concludes that the Arctic case demonstrates China's willingness and ability to break down barriers and to elevate its participation in international institutions and global governance.

\section{China and international institutions}

Traditionally, China is neither enthusiastic in building international organizations, nor particularly in favor of multilateralism in international cooperation. For example, China's contribution to United Nations institutions (both monetary and personnel) had

Fengshi Wu - PhD., Associate Professor, S. Rajaratnam School of International Studies, Nanyang Technological University, 50 Nanyang Avenue, Singapore 639798; isfswu@ntu.edu.sg

(c) Санкт-Петербургский государственный университет, 2016 
been the least impressive among all 'middle range powers' in world politics including India, Japan, Germany and Brazil up until the 2010s [7]. However, since Xi Jinping took office in 2012, China has presented the world with a series of spectacular initiatives for multilateral cooperation such as the Silk Road Fund, the Free Trade Area of Asia Pacific Framework, the Asian Infrastructure Investment Bank (AIIB), and the One-Belt-OneRoad initiative ${ }^{1}$. It is reasonable to argue that there has been a mentality shift from 'hiding brightness' (taoguan yanghiu) to 'striving with vigor' (fenfa youwei) and 'great renaissance' (weida fuxing) among the top decision makers in China, who have gradually digested the reality that Chinese domestic and diplomatic actions are 'major determinants' of any success in global governance building [8].

China's participation in global governance: Four types of status and pathways of change

\begin{tabular}{|c|c|c|c|}
\hline \multirow[b]{2}{*}{ Issues } & \multirow[b]{2}{*}{ Governing institutions } & \multicolumn{2}{|c|}{ China's participation } \\
\hline & & Current status & $\begin{array}{l}\text { Pathway of } \\
\text { change }\end{array}$ \\
\hline \multicolumn{4}{|c|}{ Energy } \\
\hline \multirow[t]{4}{*}{ Fossil fuel } & $\begin{array}{l}\text { Organization of Petroleum Exporting } \\
\text { Countries (OPEC) }\end{array}$ & \multirow[t]{4}{*}{ Non-member } & \multirow[t]{4}{*}{ Push in } \\
\hline & Gas Exporting Countries Forum & & \\
\hline & $\begin{array}{l}\text { Organization for Economic Development } \\
\text { and Cooperation }\end{array}$ & & \\
\hline & International Energy Agency & & \\
\hline Civil nuclear & Nuclear Energy Agency & Non-member & Push in \\
\hline General & U.N. International Energy Forum & Member & Leadership \\
\hline \multicolumn{4}{|c|}{ Resource } \\
\hline $\begin{array}{l}\text { Water } \\
\text { (non-navigation use) }\end{array}$ & U.N. Water Convention & $\begin{array}{l}\text { Non-member, } \\
\text { rejection }\end{array}$ & \begin{tabular}{|l|} 
Remain \\
non-member
\end{tabular} \\
\hline Forestry & U.N. Forestry Forum & Member & Leadership \\
\hline \multicolumn{4}{|c|}{ Other global public affairs } \\
\hline \multirow[t]{2}{*}{ Wildlife } & $\begin{array}{l}\text { Convention on International Trade in } \\
\text { Endangered Species }\end{array}$ & \multirow[t]{2}{*}{$\begin{array}{l}\text { Member, under } \\
\text { criticism }\end{array}$} & \multirow[t]{2}{*}{ Resist criticism } \\
\hline & Convention on Biodiversity & & \\
\hline Aerosphere & $\begin{array}{l}\text { U.N. Framework for Climate Change } \\
\text { Convention }\end{array}$ & Member & Leadership \\
\hline Nuclear security & U.N. Conference on Disarmament & $\begin{array}{l}\text { Member, under } \\
\text { criticism }\end{array}$ & Resist criticism \\
\hline Trade & World Trade Organization & Member & Leadership \\
\hline Finance & International Monetary Fund & Member & Leadership \\
\hline Human rights & $\begin{array}{l}\text { U.N. Convention on Civil and Political } \\
\text { Rights }\end{array}$ & $\begin{array}{l}\text { Member, under } \\
\text { criticism }\end{array}$ & Resist criticism \\
\hline Arctic affairs & Arctic Council & $\begin{array}{l}\text { Non-member, } \\
\text { permanent } \\
\text { observer }\end{array}$ & Push in \\
\hline
\end{tabular}

${ }^{1}$ Chinese President Xi Jinping announced the Silk Road Economic Belt plan during his state visit to Kazakhstan in September 2013. A month later, Xi proposed the 21st Century Maritime Silk Road in his address to the Indonesian parliament. Later, the Chinese government combined these two regional proposals of international development cooperation, and named it One Belt One Road initiative. 
Despite the top-down political stimulus, China faces many obstacles in enhancing its status in global governance. To begin with, China's participation in major international institutions is incomplete and highly uneven, measured by both membership and the level of international criticism (Table 1). Relatively speaking, since the 2000s China has been an active member of international trade, finance and development institutions, and a moderate complier of major international environmental treaties. Yet it also has been a reluctant member, a bystander, or even a staunch resistor to a few international régimes with regard to nuclear nonproliferation, human rights and transboundary water resource management, and as such faces high levels of international criticism and scrutiny.

In a sense, the case of World Trade Organization accession is the sweet spot, not the main pattern, of China's participation in global governance. For example, in contrast to common knowledge, China is absent from all major international governing institutions related to energy, though it has become the world's second largest consumer and biggest importer of fossil fuel in recent years [9-11]. Not a net exporter of these resources (therefore, not a member of OPEC), China will thus be unable to have a direct impact on international negotiations over oil and gas prices, so long as it is excluded from the Organization for Economic Co-operation and Development (OECD) and the International Energy Agency $(\text { IEA })^{2}$. The only major exception here is China's formal participation in the UN based International Energy Forum (IEF) - a much broader and general mechanism to facilitate communications among all member states related to world energy markets. Yet, China's IEF status was only recently changed from 'dialogue partner' to 'full member', which again indicates the nascent beginning of its inclusion in global governance of energy.

\section{Four pathways of change}

Due to its incomplete inclusion, variant membership status and uneven participation, China has acted differently with regard to various international regimes since the 2000s, though with the same goal of enhancing its presence and impact. As China intends to transform from a regular to a more significant player in global governance, there have emerged four pathways of change in its behavior. The first pathway highlights a sharp ascent of China's presence in an issue area where it has been relatively a good complier of the existing governing regime and principles (such as trade, finance and development). Marked by assertive actions to protect its own interests, active advocacy for reform and increasing pursuit of institutional leadership, China's status has risen significantly within the governing structures of the World Bank, International Monetary Fund and the Asian Development Bank. Along this path, China has also employed the method of launching an alternative multilateral institution to enjoy a type of decision-making power exclusive to a 'founding member' that had never before been available to her. The above mentioned AIIB is an exact case in point here.

The second pathway of China's rise in global governance starts with the scenario where China has already signed an international treaty yet remains resistant to the prescribed norms, principles and commitments. Unlike the first pathway, this one will only witnesses unremarkable or even an absence of change in China's behavior. Despite being a signatory to all U.N. human rights related conventions, China will not comprise its stance,

${ }^{2}$ The OECD has invited China to be a partner state recently, and at least four Chinese staff now work at the IEA headquarters in Paris to coordinate China's interests with international oil price negotiations. 
fully accept all the criticism, or reform domestic policies to meet the standards set by these treaties. Instead, China will continue to bypass, 'pay lip service' and maneuver in international negotiations and human rights governance as evidenced by its behavior at the U. N. Human Right Council since 2006 [12]. In addition, when China deems necessary, it will refuse to sign new treaties in this field such as the Rome Statute of the International Criminal Court [13].

Similar to the second, the third pathway also implies little change in China's international behavior in the areas where it is officially a bystander - a voluntary absentee of global top-down governance. If China was able to endure all the cost and pressure of not accepting certain international norms or practices before, it probably could do so even more from now on. For example, the U.N. Convention on the Protection and Use of Transboundary Watercourse and International Lakes (a.k.a. the U.N. Water Convention) was opened for signature in 1997 and won broad support among U.N.members. However, China and several upstream countries including Turkey decided to not to take part in it. This Convention went into effect on 17 August 2014, and there is no sign of China becoming a signatory soon, which in a way discourages the countries in South Asia (and other countries that have disputes with China over shared water resources) to rectify it on time [14].

The fourth pathway, including cases where China is still excluded by global governing institution in a specific issue area, will see many major changes in China's activity. Along this pathway, China is expected to make significant efforts to 'push in'. Although the number of such cases is not great, some of them are of strategic importance such as oil and gas. Both OECD and IEA have been lobbied by various Chinese agencies to reform the membership requirements so as to allow China to join in or play a bigger part [15]. Moreover, China has experimented with different venues to improve its options outside of the formal governing structures (made up by OPEC, OECD and IEA) such as strengthening bilateral energy relations with individual fuel export countries [16]. As China tries to change its non-member status in some areas of global governance, it will run into intense negotiations with the existing key stake-holders. However, in distinction from the first pathway where China has already been included in the international regime of a specific issue (such as the WTO in trade), China will hardly break away from the existing framework of global governance or build up an alternative framework (such as the AIIB in the field of international development) along the fourth pathway. The reason for this lies not only in the high cost of building a new institution and attracting membership, but the fact that the People's Republic lacks experience in participating in the management of global policies in a specific field: China is not prepared to offer the world a convincing alternative plan. For example, its very preliminary effort to build up its own network countering the existing global governance over the internet such as hosting the World Internet Conference has met with limited, if not rare, response. State heads from only eight countries attended this conference in Zhejiang province, eastern China, on 16 December 2015.

\section{China's 'push in' strategy and the Arctic}

Because of the existing governing structures of the Arctic and the set-up of the Arctic Council, China, like any other country, is left with no alternative option but to elbow in if it wants to be seriously involved in Arctic affairs [17]. The case of the China-Arctic relationship fits in the above fourth pathway analogy at the moment. The implication is 
three-folded: Firstly, China will try its best to push its way into the game and to become a part of the decision-making processes, even without a full membership. This point is mostly demonstrated by its successful attainment of the permanent observer status of the Arctic Council in 2014 [18].

Secondly, as a full membership of the Arctic Council is not possible in the foreseeable future, China will pursue alternative strategies to optimize its outside standing, particularly through bilateral and business channels. In recent years, China has made the Arctic among the top priorities in its bilateral relations with all of the Nordic countries and successfully negotiated a bilateral Arctic initiative with Iceland [19, 3]. After the conservative political force took power in Norway in 2013, the bilateral relationship between China and Norway gradually picked up momentum after a dip as the result of the 2011 Nobel Peace Prize. Recent reports show growing interest from the Norwegian side to accept Chinese state oil company and let China invest in its own eastern Barents Sea, and even possibly other Arctic areas [20]. In addition, given the history and the ongoing attempt to form a Sino-U.S. bilateral framework of carbon emission reduction, it is not far-fetched to project that China and the U.S. would negotiate a mutual agreement related to Arctic affairs independent from the Arctic Council [21].

In the wake of the Ukrainian crisis, followed by Western sanctions and declining global oil prices, Russia and China have come closer as strategic partners at the global level, and the Arctic has gradually emerged, among many others, as an area for potential long-term cooperation. As Russia is a major power in international negotiations related to the Arctic, its willingness to cooperate with China in specific sectors such as sea navigation and energy exploration could open unprecedented opportunity for China to enhance its presence and outreach in the Arctic region. The 20th Regular Meeting of China-Russia Prime Ministers took place in Beijing on 17 December 2015, and, for the first time, bilateral cooperation between the two countries in Arctic sea route and navigation was included the Joint Declaration based on the meeting [22]. To many keen observers, such joint documents and collaboration could mark significant advancement of China's participation in Arctic affairs $[23,24]$.

Besides directly engaging the Arctic Council member countries via normal diplomatic channels, the Chinese government has been keen in supporting Chinese state owned fossil fuel companies to expand their economic networks in Arctic regions, particularly through Russian territories. For example, Rosneft and its Chinese counterparts are interested in developing natural gas projects in both the Barents Sea and the Pechora Sea, and establishing joint ventures. China is also reported to control 20 percent stake in Novatek's Yamal liquified natural gas (LNG) project, and take part in the development of Novatek's Arctic LNG 1, Arctic LNG 2 and Arctic LNG 3 projects in the Gydan Peninsula [25].

Lastly, with both accumulated experiences in world affairs and enhanced state capacity, China could employ innovative methods to carve out a niche to affect the Arctic governance in a way that would at least reduce impediments to its own interests. In this aspect, the most impressive feature in China's efforts in Arctic governance is its rhetorical skill and savvy utilization of international legal languages. As Oran Young accurately pointed out, Arctic governance entered a 'new era' of governance during the 2000s, turning from 'a distinctive region with a policy agenda of its own' to a region with 'tightened' connections to the broader planetary system and therefore non-Arctic countries [26]. At this critical juncture in the political history of the Arctic, it is China more than any other rising 
power which has most vocally advocated that the Arctic needs to be discussed in broader legal frameworks. 'Chinese perspectives [on Arctic affairs] draw a distinction between purely Arctic issues and Arctic issues of interest to the broader international community and express a strong interest in playing a role in addressing the broader issues' [26, p. 167]. Many can treat this type of Chinese rhetoric as merely a cover for its mercantilist pursuits, but such a perspective is not at odds with the progressive trends in global governance, highlighting participation, equity, transparency and other principles. In a way, China's Arctic rhetoric has a potential to be used by any other non-Arctic countries, or even international agencies, that do not have an existing presence in Arctic governance.

In addition, despite all the ironies and controversies, China has effectively utilized the language of the U.N. Convention on the Law of the Sea (UNCLS), particularly the sections related to navigation, in its handling of Arctic affairs. In his public speech given on the U.N. Day of 2014 (later published in the Chinese Journal of International Law), Wang $\mathrm{Yi}$, current Chinese Foreign Minister, referred to China's stance on Arctic governance as an example of how China 'defends the rule of law in international politics' [27]. At the opening session of the 3rd Arctic Circle Assembly held on 16 October 2015, in Reykjavik, Iceland, Wang gave a video message and again explicitly stated that the rights of nonArctic countries under international law in the Arctic and the collective interests of the international community should be respected' [28]. Thus, China's using of the languages of the UNCLS is not tied only to its own claims but in the name of the whole international community.

Moreover, Chinese scholars and policy experts have constructed a concept, 'nearArctic (jin beiji) states', to advocate for the legitimacy of China's involvement in Arctic affairs, which can be viewed as a direct response to the terms such as 'Arctic coastal states', 'Arctic bordering states' and 'Arctic states' used by the Arctic Five and/or the Arctic Council respectively. This term 'near-Arctic' has already been widely used in the Chinese media, academic writings and even (semi-)official speeches such as Op-Ed pieces published in the People's Daily - the central official media outlet ${ }^{3}$. When the Chinese Vice Foreign Minister gave his keynote speech in Reykjavik recently, he defined China as a 'near-Arctic' country and stated that 'ecological changes and resource development in the Arctic have a direct impact on China's climate, environment, agriculture, shipping, trade and socio-economic development ${ }^{4}$. According to Chinese Arctic experts who have regular exchanges with their counterparts in other countries, this term could be potentially appealing to other countries such as Korea, Japan, Kazakhstan and even Britain when they also see the need to get more involved in Arctic affairs 5 .

China's potential in utilizing rhetorical tools and mobilizing for normative support in its Arctic agenda should not be under-estimated. Ever since the Mao Zhedong-Zhou

${ }^{3}$ As China so far has not published an official Arctic white paper, the Op-Ed that appeared in the People's Daily [29] has been viewed by most Chinese experts as a semi-official Arctic policy document. Much of the points included in this upbeat article is based on the logic that China is in fact a 'near Arctic' and relevant party to the future of the Arctic region and the Northern shipping route. The author thanks Professor Guo Peiqing for pointing out the relevance of the Op-Ed piece.

${ }^{4}$ See [30] for the original Chinese speech. In the official abbreviated English translation of the speech, the term 'near-Arctic' was removed, see [31].

5 This follows the author's observations gathered at the China-Canada Arctic Forum held in Shanghai $(15 / 11 / 2014)$ and the 4th International Workshop on Arctic Policy in the XXI Century held in St. Petersburg $(24 / 04 / 2015)$. 
Enlai era, China's diplomacy has not been short of distinctive idioms, doctrines and proposals of fundamental principles in world politics, such as 'seeking common ground while reserving differences (qiutong chunyi, heping gongchun)' and 'peaceful co-existence (hepi gongchu)'. Among others, the case of China's advocacy for the principle of Common But Differentiated Responsibility (CBDR) merits particular attention, as it illustrates China's ability in generating norms in global governance. While this principle has already been widely adopted in global climate negotiations, little is known to the general public that China has played a critical role in the formation and operationalization of it from the very beginning. During the last session of the 1972 U.N. Conference on the Human Environment, China, led by its legendary Premier Zhou Enlai at the time, proposed ten points for further discussion and called for a new working group to draft the final Conference Declaration. The core of these ten points was to draw a clear line between the capability and responsibility of developed and developing countries. As a result, two entirely new principles were added to the Stockholm Declaration: underlining the need to balance development with environmental protection, and every country's right to decide its own environmental standards [32]. This is the beginning of the emergence of the CBDR principle. In the following three decades, China, often joined by India and other leading developing countries, has pushed for continuous attention to and formal adoption of this principle in international negotiations [33]. In more and more cases of regional and multilateral relations where China plays a leading role, Chinese leaders bring up the CBDR principle, such as the meetings of the World Trade Organization and among the BASIC countries (Brazil, India, South Africa and China) in recent years.

In a way, '(b)y faming its opposition to binding commitments in the language of CBDR, China uses rhetoric that resonates deeply with the views and shared identity of the developing world' $[29$, p. 4]. Thirteen years after the launching of a 'global war on terror', American hegemony is declining not merely in military or economic terms, but, probably more importantly, in its global appeal and normative leadership. Failing to break through the stalemate at the negotiation tables for global public good, the American government is losing its normative power in global governance. Against this background, China's advocacy of the kinds of norms that read very differently from what have made up the existing global governance may be of more than trivial importance.

\section{Conclusion}

In the context of China's partial participation in global governance, president $\mathrm{Xi}$ has launched an ambitious plan to create more political space for China to play a bigger role in multilateral and global institutions. And the Arctic is an issue area where China has been actively experimenting with various tactics to overcome structural obstacles, to advance its position in an existing multilateral institution, and to make the best out of its outside position by engaging member states bilaterally.

The paper also highlights that the Arctic appears to be one of the global governance areas where China is keen in promoting not merely its presence but also its normative principle for the international society. The Chinese narrative on the Arctic has been firmly anchored in international laws of seas and explicit about the common entitlement to the potential resource and navigation routes in the region. This position reflects the Chinese government's stance on the right to develop and equity in sharing natural resources on the 
planet. This overall orientation will not shift in the short run. A domestic environmental movement is on the rise, but not strong enough to persuade the Chinese leadership to take up the conservationist approach in Arctic affairs. Within the Arctic Council, negotiations are sometimes clouded by security concerns, particularly for Russia and the U.S. Therefore, the possibility for an Antarctic-like move for the Arctic and for a more broad governing structure to emerge is still slim. Given the political realities in the Arctic region, the Chinese narrative of development and equity may be in fact appealing to nonArctic bordering countries and prove ripe for the mobilization of reform in the future.

\section{References}

1. Campbell C. China and the Arctic: objectives and obstacles. U.S.-China Economic and Security Review Commission Staff Research Report. 13/04/2012.

2. Jakobson L., Peng J. China's arctic aspirations. SIPRI Policy Paper, no. 34. 11/2012.

3. Guschin A. Understanding China's Arctic policies. The Diplomat, 14/11/2013.

4. Humpert M. The Future of Arctic Shipping: A New Silk Road for China? The Arctic Institute (Center for Circumpolar Security Studies). Washington, D.C., 2013.

5. Reardon S. China in the Arctic: less fish, more oil? New Scientist, 2013, vol. 218 (2919).

6. Lanteigne M. China's emerging Arctic strategies: Economics and Institutions. Centre for Arctic Policy Studies, University of Iceland. Available at: http://english.nupi.no/Publications/Books-and-reports/2014/ China-s-Emerging-Arctic-Strategies-Economics-and-Institutions (accessed 01.11. 2014).

7. Wang H., French E. Middle range powers in global governance. Third World Quarterly, 2013, vol. 34 (6), pp. 985-999.

8. Garnaut R. China's role in global climate change mitigation. China \& World Economy, 2014, vol. 22, pp. $2-18$.

9. Kong B. Governing China’s energy in the context of global governance. Global Policy, 2011, vol. 2, pp. 51-65.

10. Dubash N. K., Florini A. Mapping global energy governance. Global Policy, 2011, vol. 2, pp. 6-18.

11. Van de Graaf T., Westphal K. The G8 and G20 as Global Steering Committees for Energy. Global Policy, 2011, vol. 2. pp. 19-30. 2012.

12. Sceats S., Breslin S. China and the International Human Rights System. London, Chatham House,

13. Tao J. China's socialization in the international human rights regime: Why did China reject the Rome Statute of the International Criminal Court? Journal of Contemporary China, 2015, vol. 24 (96), pp. 10921110.

14. Ebrahim Z., Gupta J., Liu Q., Bhushal R. China, South Asia ignore UN Watercourses Convention. TheThirdPole.net. 18/08/2014. Available at: http://www.thethirdpole.net/china-south-asia-ignore-unwatercourses-convention (accessed 20.05.2015).

15. Global Energy Governance Reform and China's Participation. Consultation Report China's National Development and Reform Commission \& the Grantham Institute, Imperial College London. 2014. Available at: https://workspace.imperial.ac.uk/climatechange/Public/pdfs/.

16. Economy E., Levi M. A. By All Means Necessary: How China's Resource Quest Is Changing the World. New York, Oxford University Press, 2014.

17. Young O.R. Arctic tipping points: Governance in turbulent times. Ambio, 2012, vol. 41 (1), pp. $75-84$.

18. Willis M., Depledge D. How we learned to stop worrying about China's Arctic ambitions. The Arctic Institute. 09/2014. Available at: http://www.thearcticinstitute.org/2014/09/092214-China-arctic-ambitionsarctic-council.html (accessed 01.11.2014).

19. Sørensen C. T.N. Changing geopolitical realities in the Arctic region: possibilities and challenges for relations between Denmark and China. Bulletin on International Studies of the Polar Regions, 2014, vol. 2, pp. 2-7.

20. Holter M. Norway embraces Chinese cash in race for Arctic oil riches. Bloomberg News, 12/11/2014. Available at: http://www.bloomberg.com/news/2014-11-12/norway-embraces-chinese-cash-in-race-forarctic-energy-riches.html.

21. Wu F., Xu Y. Sino-American environmental relations. Issues and Studies, 2013, vol. 49(3), pp. 73-110. 
22. China-Russia Joint Declaration. Xinhua News Agency. 2015. Available at: http://news.xinhuanet.com/ world/2015-12/18/c_1117499329.htm (15.12.2015).

23. Baker B.D. Sino-Russian relations in the Arctic: Thawing out or freezing up? The Diplomat, $08 / 10 / 2014$.

24. Kuersten A. Russian Sanction, China and Arctic. The Diplomat, 03/01/2015.

25. Staalesen A. In Russia-China alliance, an Arctic dimension. Barents Observer. 14/11/2014. Available at: http://barentsobserver.com/en/arctic/2014/11/russia-china-alliance-arctic-dimension-14-11.

26. Young O. R. Arctic governance: pathways to the future. Arctic Review on Law and Politics, 2010, vol. 1 (2), pp. 164-185.

27. Wang Y. China: a staunch defender and builder of the international rule of law. Chinese Journal of International Law, 2014, vol. 13 (4), pp. 635-638.

28. Wang Y. Speech before the Arctic Council. Available at: http://www.fmprc.gov.cn/mfa_eng/ zxxx_662805/t1307451.shtml (accessed 15.12.2015).

29. People's Daily. Jiji Canyu Beiji Shiwu (Participate in Arctic Affairs with Vigor), (22/05/2013).

30. Speech of Chinese Vice Foreign Minister (Chinese). Available at: / http://mp.weixin.qq.com/s?_bi $\mathrm{z}=\mathrm{MzA} 4 \mathrm{NTcyMzI3Mw}==\& \mathrm{mid}=400064592 \& \mathrm{idx}=1 \& \mathrm{sn}=9413 \mathrm{~cd} 1677 \mathrm{~b} 75 \mathrm{eaa} 63 \mathrm{a} 95 \mathrm{e} 6433817 \mathrm{~d} 8 \mathrm{e} \& \mathrm{sce}$ ne $=0$ wechat_redirect (accessed 15.12.2015).

31. Speech of Chinese Vice Foreign Minister (English). Available at: http://www.fmprc.gov.cn/mfa_eng/ wjbxw/t1307440.shtml (accessed 15/12/2015).

32. Aaronson T. World priorities. Environment, 1972, vol. 14 (6), pp. 4-13.

33. Stalley P. Principled strategy: the role of equity norms in Chinas climate change diplomacy. Global Environmental Politics, 2013, vol. 13 (1), pp. 1-8.

For citation: Fengshi Wu. China's ascent in global governance and the Arctic. Vestnik of Saint Petersburg University. Ser. 6. Political science. International relations, 2016, issue 2, pp. 118-126. DOI: 10.21638/11701/ spbu06.2016.211

Статья поступила в редакцию 13 января 2016 г., рекомендована в печать 10 марта 2016 г. 